\title{
Effects of injection time of pregnant mare's serum gonadotropin and individual rams on fertility of ewes in a trial of out-of-season breeding
}

\author{
Yutaka FukuI, Masayuki KoBAYASHI and Hitoshi ONO \\ Department of Meat Animal Reproduction, Obihiro University of \\ Agriculture and Veterinary Medicine, Obihiro 080
}

\begin{abstract}
Summary. Two trials were conducted to evaluate effects of injection time of pregnant mare's serum gonadotropin (PMSG), gonadotropin releasing hormone ( $\mathrm{GnRH}$ ) and individual rams on fertility in seasonally anestrous Suffolk ewes. Trials 1 and 2 were carried out at 2 . weeks apart during April to May. Hormonal treatments were; I) $60 \mathrm{mg}$ 6-methyl-17-acetoxyprogesterone (MAP) vaginal sponge for 9 days insertion, 600 IU PMSG at the time of sponge removal and a $100 \mu \mathrm{g} \mathrm{GnRH}$ injection at estrus detection, II) MAP sponge for 9 days and 600 IU PMSG 2 days before sponge removal, and III) II)+the GnRH injection. In Trials 1 and 2, 50 and 60 ewes were used, respectively. For natural mating, 5 mature Suffolk rams were used to compare the reproductive efficiency. In Trial 1, proportions of estrous ewes within 4 days after treatment and lambing rates were not significantly different among the groups $(92.9 \%$ and $53.8 \%, 85.7 \%$ and $58.3 \%, 92.3 \%$ and $58.3 \%$ for groups I, II and III, respectively). However, there were significant differences in both proportions of estrous ewes $(P<$ $0.05)$ and lambing rates $(P<0.05)$ among the rams used. In Trial 2, group II showed a significantly higher lambing rate $(57.1 \%)$ than group I $(15.8 \%)$, although the proportion of estrous ewes in group II was significantly low $(P<0.05)$. Lambing rates in Trial 2 significantly decreased as compared with Trial 1 , but not for the proportion of estrous ewes and prolificacy. It appears that the repeated uses of the same $5 \mathrm{rams}$ at 2-weeks apart lowered fertility in Trial 2. The present study indicates that a $\mathrm{GnRH}$ injection may be unnecessary if the injection of PMSG was given 2 days before sponge removal. The PMSG injection 2 days before the progestogen withdrawal and the use of rams with high libido and semen quality could induce improvement of fertility in hormonally treated ewes during the nonbreeding season.
\end{abstract}

(Japan. J. Anim. Reprod., 31, 16-24, 1985)

\section{Introduction}

Fertile estrus can be induced in anestrous ewes treated with exogenous progestogen and pregnant mare's serum gonadotropin (PMSG). However, fertility is variable depending on methods of progestogen treatment, season, age of ewe, lactational and nutritional statuses, individuality of rams used for mating or artificial insemination (A.I.), and others. Timing of PMSG injection is also one of factors influencing fertility.
Many workers have given PMSG in ewesat the time of progestogen withdrawal ${ }^{1-3)}$. However, RoBERTS and EDGAR ${ }^{4}$ demonstrated that the administration of 750 IU PMSG 2 days before removing the vaginal sponge containing 6-methyl-17-acetoxyprogesterone (MAP) resulted in better synchronization of estrus with an associated increase in the percentage of pregnancies (87\%). STEELEBODGER $^{\text {s) }}$ and FukUI et al. ${ }^{\text {) }}$ also confirmed the effectiveness of PMSG injection 2 days before the progestogen withdrawal. In 
relation to time of PMSG administration, the necessity of gonadotropin releasing hormone $(\mathrm{GnRH})$ for improved luteal function and lowered embryonic wastage is still unclear in seasonally anestrous ewes ${ }^{8,7)}$.

In the present study, individuality of rams used for natural mating was emphasized to determine a major factor on fertility at outof-season breeding ${ }^{9,8)}$. The objectives of the study was to compare five sires of Suffolk breed for the efficiency of estrus detection, fertility and prolificacy in seasonally anestrous ewes treated with one of three hormonal treatments including different times of PMSG injection and the effect of $\mathrm{GnRH}$ at the induced estrus.

\section{Materials and Methods}

For Trials 1 and 2, the animals had been kept in a D-type house under natural light conditions during the study. The rams had been keeping in a stud completely isolated at least three months from the ewe flock. The animals were fed one kg hay per head (given twicely daily) and a concentrate pellet containing $16 \%$ crude protein (about $200 \mathrm{~g}$ per head daily), and allowed free access to water, salt and mineral blocks.

Trial 1. The vaginal sponge containing $60 \mathrm{mg}$ MAP (The Upjohn International Ltd., Australia) was inserted into the vagina for 9 days in 50 ewes from a flock of 110 mature (2-6 years old) Suffolk ewes on April 11th, 1984. Of 50 ewes, 9 ewes lost sponges during the insertion period and 41 ewes were then subjected to treat for Trial 1. Hormonal treatments were as floows; I) i.m. injection of $600 \mathrm{IU}$ PMSG (Teikoku-zoki Co. Ltd., Japan) at sponge removal and i.m. injection of $2 \mathrm{ml}(100 \mu \mathrm{g})$ synthtic GnRH (Conceral:
Takeda Industrial Co., Japan) at observed estrus, II) i.m. injection of $600 \mathrm{IU}$ PMSG 2 days before sponge removal, and III) i.m. injection of PMSG 2 days before sponge removal and the $\mathrm{GnRH}$ injection at observed estrus. The number of treated ewes per group were 14, 14 and 13 for groups I, II and III, respectively. At the time of sponge removal, all ewes were randomly divided into five sub-groups for natural mating by five Suffolk rams (Ram A: 3 years old, Ram B: 4 years old, Ram C: 3 years old, Ram D: 2 years old, and Ram E: 14 months old) fitted with 'Sire-Sine' harnesses and crayons. Each ram and 8 to 9 ewes from groups I, II and III were joined into a $5 \times 8 \mathrm{~m}$ pen. Estrus was examined $4 \mathrm{~h}$ intervals for 4 days after joining. At the time of estrus, detection, the ewes of groups I and III were given a $\mathrm{GnRH}$ injection. After 4-days joining period, rams were withdrawn from each pen for resting.

Trial 2. A similar experiment as Trial 1 was conducted using 60 remaining ewes in the flock. MAP sponges were inserted to ewes on April 25th, 1984. During the 9-days insertion period, 5 ewes lost their sponges. Therefore, 55 ewes were used for the hormonal treatment as Trial $1(19,18$ and 18 ewes for groups I, II and III, respectively). The same rams were used again for natural mating at the time of sponge removal. In Trial 2, each ram was joined to 9 to 12 ewes randomly selected from each group in the pen. Estrous ewes were defined 'marked' by rams fitted with the harnesses and crayons at $4 \mathrm{~h}$ observations for 4 days after joining.

For both Trials 1 and 2, all marked ewes were received an im injection of $100 \mathrm{IU}$ 
human chorionic gonadotropin (hCG: Teikokuzoki Co. Ltd., Japan) on the 11th, 12th and 13th days after mating ${ }^{10)}$. Fertility was expressed as lambing and prolificacy (no. of lambs born/no. of ewes lambed) was also recorded.

Data on estrous ewes and fertility were compared by chi-square analysis. Data on prolificacy were subjected to analysis of variance, and differences were analyzed by Student's $t$-test ${ }^{11)}$.

\section{Results}

Trial 1. Results of effects of hormonal treatments and individual rams were shown in Tables 1 and 2. Proportions of estrous ewes following the treatment. were similar $(92.9 \%, 85.7 \%$ and $92.3 \%$ for groups I, II and III, respectively) with no significant difference. Incidence of estrus was earlier in ewes treated with PMSG 2 days before sponge removal (combined with groups II and III: Fig. 1) than those treated at the time of sponge removal. Lambing rates and prolificacy were not significantly different among the hormonal treatments $(53.8 \%$ and $1.57,58.3 \%$ and 1.45 , and $58.3 \%$ and 2.00 for groups I, II and III, respectively). Meanwhile, ram individuality resulted in significant differences on both estrous ewes $(P<$ $0.05)$ and lambing rate $(P<0.05)$. Although Ram A marked 7 of 8 ewes, no ewes lambed. Three rams (B, C. E) marked all ewes in the sub-group and resulted in high lambing rates (Ram B: $88.9 \%$, Ram E: 75.0\%), but not by Ram C (37.5\%). Four of 5 ewes marked by Ram D lambed (90.0\%), although the proportion of marked ewes was significantly lower $(62.5 \%, P<0.05)$ than those by Rams B, C and E. There was no significant

Table 1. Effect of hormonal treatments on estrus incidence and fertility in Trial 1

\begin{tabular}{lcccc}
\hline \hline Groups $^{\mathrm{a}}$ & $\begin{array}{c}\text { No. ewes } \\
\text { treated }\end{array}$ & $\begin{array}{c}\text { No. ewes heated } \\
(\%)\end{array}$ & $\begin{array}{c}\text { No. ewes lambed } \\
(\%)\end{array}$ & Prolificacy $^{\mathrm{b}}$ \\
\hline I & 14 & $13(92.9)^{\mathrm{c}}$ & $7(53.8)^{\mathrm{d}}$ & 1.57 \\
II & 14 & $12(85.7)^{\mathrm{c}}$ & $7(58.3)^{\mathrm{d}}$ & 1.45 \\
III & 13 & $12(92.3)^{\mathrm{c}}$ & $7(58.3)^{\mathrm{d}}$ & 2.00 \\
Total & 41 & $37(90.2)$ & $21(56.8)$ & 1.67 \\
\hline
\end{tabular}

a Group I: MAP sponge+600 IU PMSG on sponge removal+100 $\mu \mathrm{g}$ GnRH, Group II: MAP sponge +600 IU PMSG 2 days before sponge removal, Group III: MAP Sponge+600 IU PMSG 2 days before sponge removal $+100 \mu \mathrm{g} \mathrm{GnRH}$.

b No. lambs born/No. ewes lambed.

c,d The proportions in the same column were not significantly different $(P>0.05)$.

Table 2. Effect of individual rams on estrus detection and fertility in Trial 1

\begin{tabular}{lcccc}
\hline \hline Rams & $\begin{array}{c}\text { No. ewes } \\
\text { treated }\end{array}$ & $\begin{array}{c}\text { No. ewes heated } \\
(\%)\end{array}$ & $\begin{array}{c}\text { No. ewes Lambed } \\
(\%)\end{array}$ & Prolificacy $^{\mathrm{a}}$ \\
\hline $\mathrm{A}$ & 8 & $7(87.5)^{\mathrm{b}, \mathrm{c}}$ & $0(0.0)^{\mathrm{b}}$ & 0 \\
$\mathrm{~B}$ & 9 & $9(100)^{\mathrm{b}}$ & $8(88.9)^{\mathrm{d}}$ & 1.75 \\
$\mathrm{C}$ & 8 & $8(100)^{\mathrm{b}}$ & $3(37.5)^{\mathrm{c}}$ & 1.33 \\
$\mathrm{D}$ & 8 & $5(62.5)^{\mathrm{c}}$ & $4(90.0)^{\mathrm{c}, \mathrm{d}}$ & 1.75 \\
E & 8 & $8(100)^{\mathrm{b}}$ & $6(75.0)^{\mathrm{c}, \mathrm{d}}$ & 1.67 \\
Total & 41 & $37(90.2)$ & $21(56.8)$ & 1.67 \\
\hline
\end{tabular}

* No. lambed born/No. ewes lambed.

$b, c, d$ The proportions with different superscripts in the same column significantly differ $(P<0.05)$. 


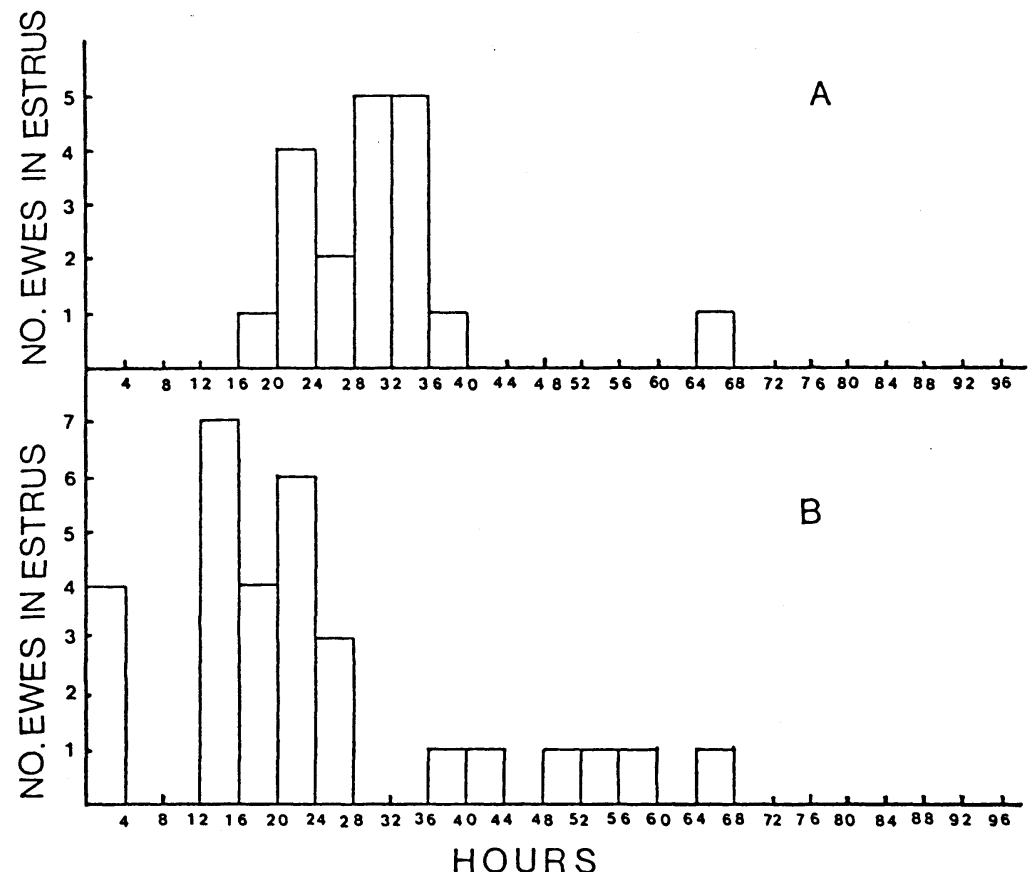

Fig. 1. The pattern of estrus incidence in ewes treated with PMSG at the removal of MAP sponge (A) or PMSG 2 days before the withdrawal (B). B is combined with the data in groups II and III (Trial 1).

Table 3. Effects of hormonal treatments on estrus incidence and fertility in Trial 2

\begin{tabular}{lcccc}
\hline \hline Groups $^{\mathrm{a}}$ & $\begin{array}{c}\text { No. ewes } \\
\text { treated }\end{array}$ & $\begin{array}{c}\text { No. ewes heated } \\
(\%)\end{array}$ & $\begin{array}{c}\text { No. ewes lambed } \\
(\%)\end{array}$ & Prolificacy $^{\mathrm{b}}$ \\
\hline I & 19 & $19(100)^{\mathrm{c}}$ & $3(15.8)^{\mathrm{c}}$ & 1.67 \\
II & 18 & $14(77.8)^{\mathrm{d}}$ & $8(57.1)^{\mathrm{d}}$ & 1.75 \\
III & 18 & $16(88.9)^{\mathrm{c}, \mathrm{d}}$ & $6(31.3)^{\mathrm{c}, \mathrm{d}}$ & 1.33 \\
Total & 55 & $49(89.1)$ & $17(34.7)$ & 1.59 \\
\hline
\end{tabular}

a The same as in Table 1.

b No. lambs born/No. ewes lambed.

c,d The proportions with different superscripts in the same column significantly differ $(P<0.05)$.

Table 4. Effect of individual rams on estrus detection and fertility in Trial 2

\begin{tabular}{lcccc}
\hline \hline Rams & $\begin{array}{c}\text { No. ewes } \\
\text { treated }\end{array}$ & $\begin{array}{c}\text { No. ewes heated } \\
(\%)\end{array}$ & $\begin{array}{c}\text { No. ewes lambed } \\
(\%)\end{array}$ & Prolificacy $^{\mathbf{a}}$ \\
\hline A & 9 & $7(77.8)^{\mathrm{b}}$ & $0(0.0)^{\mathrm{b}}$ & 0 \\
$\mathrm{~B}$ & 11 & $10(90.0)^{\mathrm{b}, \mathrm{c}}$ & $6(60.0)^{\mathrm{C}}$ & 1.33 \\
$\mathrm{C}$ & 12 & $10(83.3)^{\mathrm{b}, \mathrm{c}}$ & $2(20.0)^{\mathrm{b}, \mathrm{c}}$ & 1.50 \\
$\mathrm{D}$ & 11 & $10(90.0)^{\mathrm{b}, \mathrm{c}}$ & $5(50.0)^{\mathrm{c}}$ & 2.40 \\
E & 12 & $12(100)^{\mathrm{c}}$ & $4(33.3)^{\mathrm{c}}$ & 1.00 \\
Total & 55 & $49(89.1)$ & $17(34.7)$ & 1.59 \\
\hline
\end{tabular}

* No. lambs born/No. ewes lambed.

b,c The proportions with different superscripts in the same column significantly differ $(P<0.05)$. 


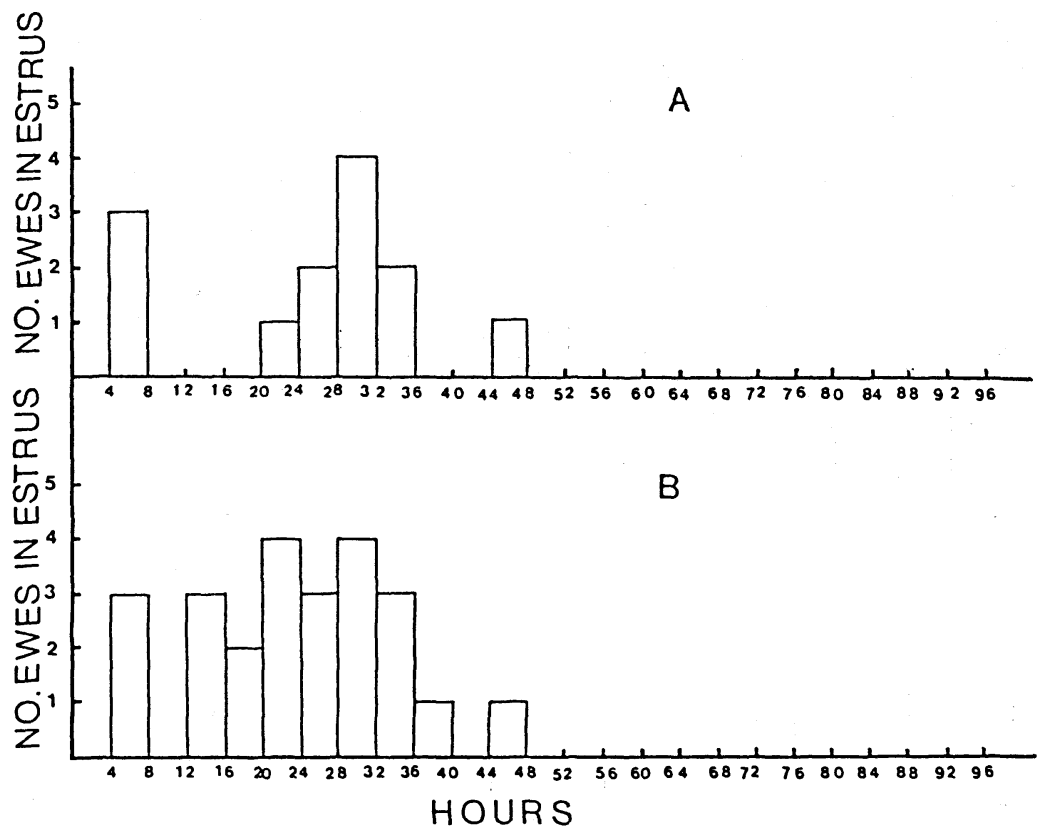

Fig. 2. The pattern of estrus incidence in ewes treated with PMSG at the removal of MAP sponge (A) or PMSG 2 days before the withdrawal (B). B is combined with the data in groups II and III (Trial 2).

difference on prolificacy among the rams.

Trial 2. Results of Trial 2 were shown in Tables 3 and 4. Again, the time of estrus onset was approximately 16 to $20 \mathrm{~h}$ earlier in ewes treated with PMSG 2 days before sponge removal than those treated at the time of sponge removal (Fig. 2). The proportions of estrous ewes in group II was significantly $(P<0.05)$ lower than in group I $(77.8 \%$ and $100 \%)$, but the lambing rate in group II was significantly $(P<0.05)$ higher as compared with group I (57.1\% and $15.8 \%)$. Between groups II and III, the proportion of estrous ewes and lambing rates were not significantly different. In group II, prolificacy was also highest among the groups, although there was no significant difference.

For ram individuality, the proportions of estrous ewes were not significantly different among the rams. However, there was a significant difference on the proportion of estrous ewes between Rams $\mathrm{A}$ and $\mathrm{E}(P<$ 0.05). It failed to reveal significant differences on fertility $(P<0.10)$ and prolificacy ( $F=3.13$ ) among rams used. Rams $\mathrm{B}$ and $D$ showed better results in lambing and prolificacy. Again, no ewes marked by Ram A lambed.

In a total of Trials 1 and 2, 14 of 110 ewes lost sponges (12.7\%). Of 96 treated ewes, 87 ewes $(90.6 \%)$ were marked by rams within 4 days after joining. Thirty-eight of those marked ewes lambed (43.6\%) and produced 62 lambs (1.63). However, 9 of 62 lambs born (14.6\%) were dead after birth. Lambing rates in Trial 2 significantly decreased as compared with Trial 1 (34.7\% and $56.8 \%, P<0.05)$, meanwhile there were no significant difference on the proportion of estrous ewes and prolificacy between the 
Trials. The significant difference in fertility between Trials was revealed by a significant decrease $(P<0.025)$ in lambing rate of group $I$ in Trial 2. No significant difference in lambing rates of both groups II and III, and in the rams were found between Trials 1 and 2 .

\section{Discussion}

Three hormonal treatments and ram individuality were investigated in two similar trials with 2-weeks apart. The PMSG injection 2 days before the removal of MAP sponge resulted in high lambing rates in both Trials (58.3\% and $57.1 \%)$ as compared with two other methods. This indicates that a GnRH injection may be unnecessary if PMSG was administered 2 days before the progestogen withdrawal. The early onset of estrus in ewes treated with PMSG 2 days before sponge removal is likely related to a high fertility. Because the ewes were served while the rams were with a higher quality of semen after introduction as ToMkINs and BRYANT ${ }^{13)}$ suggested that to achieve maximum fertility it could be desirable for the first 20-30 ejaculates to be evenly distributed amongst the majority of estrusinduced ewes. The use of GnRH as an adjunct to ovarian stimulation may rather adversely affect estrous expression for synchronized breeding of ewes ${ }^{13)}$. FUKUI et al. ${ }^{8,7)}$ showed that a single $\mathrm{GnRH}$ injection at observed estrus increased fertility when PMSG was injected at the time of sponge removal, but no effective when it was administered 2 days before sponge removal. The effect of $\mathrm{GnRH}$ on a prolonged progesterone response ${ }^{14)}$ and reduced embryonic loss ${ }^{7}$ was only found in combined with PMSG pretreatment at the with- drawal of progestogen treatment. ROBERTS and $E_{D G A R}^{4}$ have considered that the injection of PMSG 2 days before the withdrawal of MAP sponge while progestogen is still being absorbed from the vaginal sponge, appears to stimulate normal follicle development, estrus and ovulation as during the breeding season. It has been reported that excessive estrogen preceding ovulation after PMSG administration at the progestogen withdrawal has a highly deleterious effect on fertility ${ }^{1)}$. Although blood estrogen levels were not measured in the present study, the administration of PMSG 2 days before the progestogen withdrawal may have maintained the blood estrogen within a restricted range for optimal fertility. Determinations in the release of luteinizing hormone (LH) and time and peak of $\mathrm{LH}$ surge in relation to blood estrogen levels at estrus induced by the progestogen sponge and PMSG 2 days before sponge removal would be future subjects.

Fertility in the present study was largely affected by individual rams used. The use of Ram A caused infertility. No ejaculations were observed throughout the study probably due to sufferring from the fore-leg, although ram A was used for mating from October 20th to November 30th, 1983 and found to be fertile. Libido was not tested prior to mating, but satisfactory lambing rates (75$90 \%$ ) were obtained by the use of Rams B, $\mathrm{D}$ and $\mathrm{E}$ independing on their ages in Trial 1. HACKETT and WoLYNETZ ${ }^{2}$ also reported that there was no significant effects in fertility and prolificacy for the sire strain and ram age during the late anestrous season. Several reasons of the decreased fertility in Trial 2 were considered; i) low semen quality 
by the repeated uses of the same rams with 2-weeks apart, ii) 50 ewes for Trial 1 were chosen from the flock of 110 ewes, whereas the remaining 60 ewes were used for Trial 2 . Therefore, more ewes in physiologically and/ or nutritionally low reproductive performance might have involved, and iii) number of ewes per ram increased in Trial 2. It appears that libido of each ram did not decrease as the proportion of marked ewes in Trial 2 was similar to that in Trial $1(89.1 \%$ and $90.2 \%$, respectively). The lower fertility in out-of-season breeding caused by not only the seasonal variations of estradiol-mediated LH release ${ }^{15)}$ and a high early embryonic loss $(55-62 \%)^{18,17)}$ in progestogen-treated ewes, but also the variations in the daily sperm production in rams $^{8)}$. Among these respects, early embryonic loss could be reduced by the administration of $\mathrm{hCG}^{10)}$ or $\mathrm{GnRH}^{\text {) }}$, although no improvement in fertility was observed by treatments of both $\mathrm{GnRH}$ and $\mathrm{hCG}$ in the present study, especially in group I of Trial 2.

DUFour et $a l .{ }^{9}$ ) and LUNSTRA and Christenson ${ }^{16)}$ reported that lowered seminal output and motility and percentage of live spermatozoa between rams within breeds in April and May are major factors influencing the reduced fertility of seasonally anestrous ewes. SMITH et al. (cited by GORDON $^{18)}$ ) reported that semen from Suffolk rams was less fertile than that of Dorset rams in spring breedings. Therefore, selection of rams in a breed with a high quality of semen and possibly high libido would be the most important factor influencing the fertility for out-of-season breeding. Photoperiod manipulations would be an alternative mean to faciliate out-of-season breeding in many breeds of sheep ${ }^{2,3)}$.

The ram-to-ewe ratio recommended after synchronization is usually one ram to 10 to 15 ewes. LASTER and GLIMP ${ }^{10)}$ and BRYANT and TOMKINS ${ }^{20)}$ found no significant difference between conception rates when rams were mated to groups of 8 to 20 and 6 to 30 ewes, respectively. However, BRYANT and TomkINS ${ }^{20)}$ observed that as number of ewes per ram increased, the ewes had to wait longer for their first service and were served less often. The semen volume and numbers of spermatozoa per ejaculation also decreased to an extent comparable with a sample used for A.I., although rams may readily serve up to 20 or 30 times in one day ${ }^{12,21)}$. In flock mating, therefore, number of services per ewe and the order of ejaculations by each ram depending on ram-to-ewe ratio appears to affect on fertility in connection with the time of ram introduction ${ }^{22)}$. Due to these circumstances, hand mating by rams with good libido and high quality of semen may be more efficient than the flock mating with a low ram-to-ewe ratio ${ }^{20,23)}$.

In conclusion, the injection of PMSG could be given 2 days before the progestogen withdrawal in seasonally anestrous ewes. This may be eliminated the use of $\mathrm{GnRH}$ without decreasing fertility of mated ewes. Fertility differed depending on individual rams used.

\section{Acknowledgements}

The authors express our thanks to Tawa Field Station, Shibechya-cho, Hokkaido, Japan for uses of animals and facilities, $D_{R}$. S. H. LAngford, The Upjohn International Ltd., Australia and Teikokuzoki Co. Ltd., Japan for the supply of MAP vaginal sponges and PMSG, respectively, and $D_{R}$. R. W. Wright, Jr., Department of Animal Science, Washington State University, U.S.A. for reading the manuscript with valuable comments. This 
1985 年 3 月

study was supported in part by a grant-in-aid from the Hokkaido Newspaper Co., Japan.

\section{References}

1) Evans G \& TJ Robinson: J. agric. Sci. Camb., 94, 69, 1980.

2) Hackett AJ \& MS Wolynetz: Can. J. Anim. Sci., 61, 907, 1981.

3) Jeffcoate IA, NC Rawlings \& WE Howell: Theoriogenology, 22, 279, 1984.

4) Roberts EM \& DG Edgar: Nature, Lond., 212, 1948, 1966.

5) Steele-Bordger A: Vet. Rec., 84, 421, 1969.

6) Fukui $Y, M$ Kobayashi, S Takenaka, T Kimura, K EIDA \& H ONo: Jpn. J. Sheep Sci., 20, 1, 1983.

7) Fukui $\mathrm{Y}, \mathrm{S}$ Takenaka, I Domeki \& H ONo: Japan. J. Anim. Reprod., 30, 108, 1984.

8) Dacheux JL, C Pinelet, MR Blanc, MT Hochereaude Reviers \& M Courot: J. Reprod. Fert., 61, 363, 1981.

9) Dufour JJ, MH Fahmy \& F Minvielle: $J$. Anim. Sci., 58, 416, 1984.

10) Kittok RJ, JN Stellflug \& SR Lowry: $J$. Anim. Sci., 56, 652, 1983.

11) Steel RGD \& JH Torrie: Principles and Pro. cedures of Statistics (STEEL RGD \& JH ToR.
家畜繁殖誌 31 巻 1 号

RIE eds.), McGraw.Hill Book Co., New York, 1960.

12) Tomkins T \& MJ Bryant: Anim. Prod., 22, 371, 1976.

13) Lofstedt RM \& PG Eness: Theriogenology, 18, 119, 1982.

14) Kinser AR, MF Gibson, DL Vencent, NS Scheffrahn \& DJ Kesler: Theriogenology, 19, 449, 1983.

15) Echternkamp SE: Theriogenology, 18, 95, 1982.

16) Lunstra DD \& RK Christenson: J. Anim. Sci. 53, 458, 1981.

17) Rawlings NC, iA Jeffcoate, NC Savage, DMK Steuart \& LHM Steuart: Theriogenology, 19, $665,1983$.

18) Gordon I: Wld. Rev. Anim. Prod., 12, 33, 1976.

19) Laster, DB \& HA Glimp: Anim. Prod., 15, 99, 1972.

20) Bryant MJ \& T Tomkins: Anim. Prod., 20, 381, 1975.

21) Salamon S: Aust. J. Agric. Res., 13, 1137, 1962.

22) Bryant MJ \& T Tomkins: Anim. Prod., 22, 379, 1976.

23) Steffan J, P Poissonnet \& M Thibier: Anim. Reprod. Sci., 5, 191, 1983.

(Received February 6, 1985) 
めん羊の季節外繁殖に及ぼす妊馬血清性性腺刺激ホルモンの 注射時期と雄羊の個体差による影響

\author{
福井 豊・小林正之・小野 斉
}

(带広音産大学音産学部肉畜增殖学教室)

サフォーク種雃羊の季節外繁殖に及ぽす妊馬血清性性 腺刺激ホルモン (PMSG) の注射時期と性腺刺激ホルモ ン放出ホルモン (GnRH) および雄羊の個体差による影 響を検討した。

非繁殖季節である 4〜5 月に， 2 週間間隔で 2 つの実 験（実験 1:50 頭, 実験 2:60 頭）を行なった。ホルモ ン処固法は以下の如くである：I) 6-methyl-17-acetoxy progesterone (MAP) を $60 \mathrm{mg}$ 含む㨖内スポンジ (9 日間) 挿入+600 IU PMSG (MAP スポンシ除去時) +

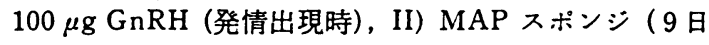
間) +600 IU PMSG (MAP スポンジ除去 2 日前)，お よび III) II) 処固 $+\mathrm{GnRH}$ (発情出現時)。MAP スポ ンジ除去後, 雄羊 5 頭を雃羊 8〜12 頭に対して 1 頭ずつ 導入し，その後 4 日間の発情出現を観察した。

実験 1 では, 発情出現率（I 群：92.9\%, II 群：
85.7\%，III 群：92.3\%) および分娩率（I 群：53.8\%， II 群: $58.3 \%$, III 群: 58.3\%) において, ホルモン処 直法に有意差は認められなかった。しかし，雄羊の個体 間において発情出現率 $(P<0.05)$ および分婏率 $(P<$ 0.01）に有意差が見られた。実験 2 では，II 群の発情出 現率は有意に $(P<0.05)$ 低かった $(77.8 \%)$ が，分婏率 はI 群に比べて有意に $(P<0.05)$ 高かった $(57.1 \%$ ， $15.8 \%)$ 。実験 2 の分婏率は実験 1 より有意に $(P<$ 0.05）低下した。これは 2 週間間隔で同じ 5 頭の雄羊を 使用したためと考えられた。

以上の結果から, PMSG 注射を MAP スポンジの除 去2 日前に実施すれば， GnRH 注射は必要ないことが 示咬された。また，季節外繁殖による受胎率は使用する 雄羊の個体差に影響されることが認められた。 